\title{
Pengembangan Aplikasi Kunci Elektronik Brankas Berbasis Android dengan Mikrokontroler Berbasis Bluetooth
}

\author{
Ilham Fahrul Rozi ${ }^{1}$, Dolly Virgian Shaka Yudha Sakti ${ }^{1, *}$, Safitri Juanita ${ }^{2}$, Muhammad Anif \\ ${ }^{1}$ Fakultas Teknologi Informasi, Teknik Informatika, Universitas Budi Luhur, DKI Jakarta, Indonesia \\ ${ }^{2}$ Fakultas Teknologi Informasi, Sistem Informasi, Universitas Budi Luhur, DKI Jakarta, Indonesia \\ Email: ${ }^{1}$ ilham.fahrul.rozi@gmail.com,,,*dolly.virgianshaka@budiluhur.ac.id, ${ }^{3}$ safitri.juanita@budiluhur.ac.id \\ ${ }^{4}$ muhammad.anif@budiluhur.ac.id \\ Email Penulis Korespondensi: dolly.virgianshaka@budiluhur.ac.id
}

\begin{abstract}
Abstrak-Brankas adalah lemari atau kotak besi tahan api yang biasa dipergunakan untuk melindungi barang-barang berharga dari bahaya kebakaran dan pencurian menggunakan kunci analog atau digital atau kombinasi keduanya. Penelitian ini membuat aplikasi kunci elektronik brankas berbasis android untuk melakukan otomatisasi buka dan tutup kunci brankas dengan bantuan mikrokontroler menggunakan bluetooth. Alur kerja aplikasi adalah aplikasi android akan mengaktifkan bluetooth pada handphone dan mengirimkan input kepada rangkaian mikrokontroler arduino untuk mengaktifkan solenoid door lock sehingga dapat membuka atau mengunci brankas. Tujuan dari penelitian ini adalah merancang dan membangun aplikasi kunci elektronik berbasis android pada brankas sehingga memiliki tingkat keamanan yang tinggi dan memiliki fitur history (log) untuk mengetahui aktifitas dari pengguna aplikasi. Metode pengembangan sistem yang akan digunakan pada pembangunan aplikasi ini adalah metode waterfall. Aplikasi akan dibangun menggunakan bahasa pemrograman Java dengan editor Basic4Android, basis data disimpan menggunakan SQLite. Kesimpulan penelitian ini adalah setelah dilakukan pengujian maka disimpulkan bahwa pengintegrasian rangkaian mikrokontroler seperti solenoid door lock, ATmega 328, Bluetooth HC-05 dan uji coba aplikasi android sebagai kunci elektronik menjadi sebuah sistem aplikasi keamanan pada brankas memiliki keamanan tinggi, alat simulasi berupa brankas dapat melakukan respon yang baik terhadap pengguna saat melakukan perintah dari Android melalui Bluetooth dalam jarak kurang dari 5 meter, sistem keamanan memiliki keamanan yang tinggi karena memiliki otentifikasi dan fitur LOG untuk mengetahui kegiatan terakhir (login dan logout) dari pengguna.
\end{abstract}

Kata Kunci: Aplikasi Kunci Elektronik, Brankas, Mikrokontroler, Bluetooth, Solenoid Door Lock

\begin{abstract}
Safety deposit box are usually used to protect valuables stuff from fire and theft using analog or digital keys or a combination of both. This research makes android based electronic lock application for safety deposit box to automate safe opening and closing keys with the help of a microcontroller using Bluetooth. The Workflow of these application is an Android application will activate Bluetooth on the cell phone and send input to the arduino network microcontroller to activate the Solenoid door lock so that it can open or lock safely. The purpose of this research is to design and build an Android application for electronic keys in a safety deposit box so that it has a high level of security and has a history (log) feature to find out the user's application activities. The system development life cycle that will be used to build this application is the Waterfall method. This application will be built using Java programming language with the Basic4Android editor, the database is stored using SQLite. The conclusion of this research is that after testing concluded that the integration of network microcontrollers such as Solenoid door locks, ATmega 328, Bluetooth HC-05 and testing Android applications as electronic keys into the application security system in safety deposit box has high security, simulation tools in safety deposit box can respond which is good for users when performing commands from Android via Bluetooth in less than 5 meters, the security system has high security because it has an authentication and LOG feature to find out the user's last activity (in and out).
\end{abstract}

Keywords: Electronic Lock Application, Safety deposit box, Microcontroller, Bluetooth, Solenoid Door Lock

\section{PENDAHULUAN}

Menurut laporan Statistik Kriminal 2019 yang dikeluarkan oleh Badan Pusat Statistik tahun 2019 [1] selama periode tahun 2016-2018 jumlah kejahatan atau tindak kriminal di Indonesia berubah-ubah, pada tahun 2017 sebanyak 336.652 jumlah tindak kejahatan dan menurun tahun 2018 menjadi 294.281 kejadian, meskipun menurut data tahun 2017-2018 tidak kriminal di Indonesia menurun, akan tetapi angka-angka tersebut masih tergolong tinggi. Berdasarkan data tersebut maka dibutuhkan sistem keamanan dengan menggunakan teknologi yang berkembang saat ini. Berdasarkan data tersebut maka dibutuhkan sistem keamanan dengan menggunakan teknologi yang berkembang saat ini. Sebagai contoh pada brankas atau lemari besi perkantoran umumnya memiliki system keamanan yang masih minim karena hanya memakai kunci biasa [2], [3]. Kunci manual ini memang dapat digunakan sebagai kunci pengaman namun kunci ini memiliki beberapa kekurangan atau resiko. Contoh kekurangan penggunaan kunci biasa adalah adanya kemungkinan pengguna lalai dan lupa mengunci brankas. Masalah lain juga dapat teradi jika kunci terselip ditempat yang tersembunyi. Selain itu brankas seperti ini masih memliki resiko tinggi seperti dibobol tanpa sepengetahuan pemiliknya [4].

Pada penelitian sebelumnya telah banyak dibahas tentang keamanan kunci brankas menggunakan RFID, SMS, dan biometrik [3]-[6]. Tetapi masih terdapat kekurangan pada masing-masing sistem. Penggunaan RFID masih memungkinkan untuk terselip bahkan hilang. Penggunaan SMS akan membutuhkan biaya tambahan untuk selalu membeli pulsa. Sedangkan penggunaan sidik jari sebagai kunci memiliki resiko kegagalan jika jari yang digunakan sebagai kunci sedang terluka. Pada penelitian tentang keamanan brankas yang sudah pernah dibuat banyak menggunakan Arduino Mega dan Arduino Uno[2], [4], [7]-[9]. Masih belum ada penelitian keamanan brankas yang menggunakan Arduino Pro Mini. Beberapa penelitian menggunakan Arduino Pro Mini untuk 
keamanan seperti keamanan loker dan keamanan sepeda motor[10]-[12]. Alasan penggunaan Bluetooth pada penelitian ini adalah karena kehandalannya. Bluetooth mampu menembus penghalang berupa tembok dan kayu[13]. Selain itu beberapa penelitian terkait keamanan brankas sebelumnya juga menggunakan Bluetooth sebagai medianya[2], [7], [13], [14].

Berdasarkan beberapa alasan di atas, maka diperlukan rancang bangun aplikasi kunci elektronik untuk mengunci brankas atau lemari besi dengan memasukkan password atau PIN melalui Android device sebagai otentifikasi menggunakan Arduino Board dengan kendali melalui Bluetooth HC-05 berbasis Android OS. Tujuan penelitian ini diantaranya merancang suatu sistem keamanan pada brankas dengan otentifikasi yang dinamis berbasis Android. Serta mengimplementasikan sistem keamanan yang lebih baik pada brankas sehingga barangbarang yang ada di dalamnya tetap aman.

\section{METODOLOGI PENELITIAN}

Langkah-langkah yang akan dilakukan dalam penelitian ini terdapat pada gambar 1: Diawali dengan melakukan penelitian pendahuluan, kemudian mengidentifikasi masalah yang ada pada masyarakat (observasi) [1]. Kemudian melakukan analisis masalah dan menemukan solusi terhadap masalah. Setelah ditemukan solusi terhadap masalah maka tahap selanjutnya adalah modelling yaitu pembangunan prototype perangkat keras yaitu brankas dengan mikrokontroler Arduino Promini, Bluetooth Module, Driver Solenoid, Solenoid Doorlock serta adaptor (Power Supply) dan melakukan desain rancangan layar perangkat lunak yang akan digunakan dalam pengembangan aplikasi android untuk kunci android. Setelah itu masuk ke tahap konstruksi yaitu membuat kode program dengan bahasa pemrograman Java dengan editor Basic4Android, dan terakhir melakukan testing dan validasi kemudian memberikan kepada User untuk memberi tanggapan dan terakhir membuat kesimpulan dari penelitian.

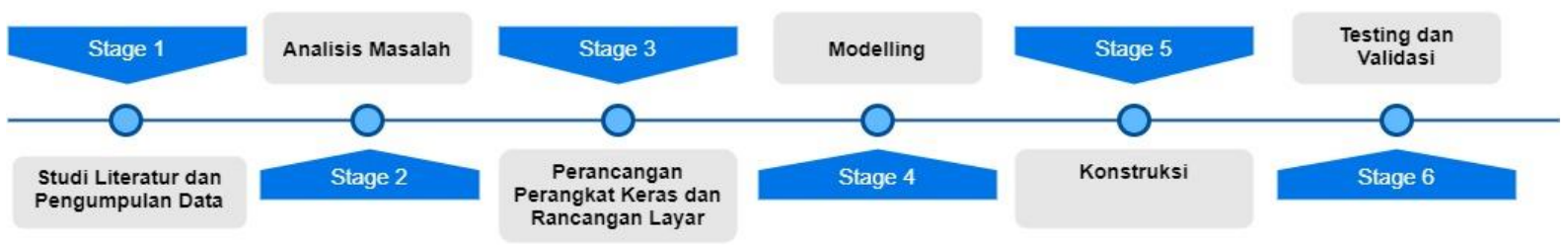

Gambar 1. Desain Penelitian

\section{HASIL DAN PEMBAHASAN}

\subsection{Analisa kebutuhan Fungsionalitas Sistem}

Pada tahap ini, dilakukan analisa kebutuhan fungsionalitas sistem pada Aplikasi Android untuk kunci elektronik pada Brankas dalam bantuk use case diagram pada gambar 2, aplikasi ini memiliki 5 fitur dimana user atau pengguna bisa menggunakan semua fungsi atau fitur yaitu login yang berfungsi melakukan autorisasi pengguna, fitur melihat panduan yang membantu user dalam menggunakan aplikasi, fitur mengubah data user yang akan membantu pengguna untuk mengatur profil dan mengganti password, fitur melihat data log user yang berfungsi untuk mengetahui kapan user terakhir login atau masuk dan kapan user terakhir logout atau keluar, fitur membuka dan mengunci brankas yang digunakan untuk membuka dan menutup brankas secara otomatis dari handphone. Pada fitur mengubah data user, data user akan disimpan ke basis data SQLite.

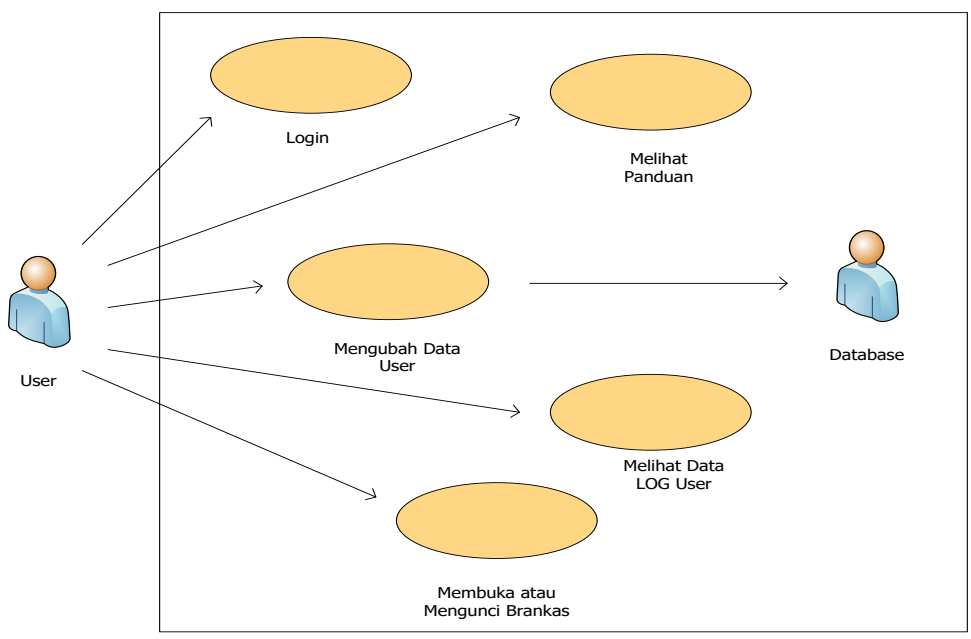

Gambar 2. Use Case Diagram Aplikasi Android untuk Kunci Elektronik Pada Brankas 
JURNAL MEDIA INFORMATIKA BUDIDARMA

Volume 4, Nomor 3, Juli 2020, Page 693-699

ISSN 2614-5278 (media cetak), ISSN 2548-8368 (media online)

Available Online at https://ejurnal.stmik-budidarma.ac.id/index.php/mib DOI 10.30865/mib.v4i3.2189

\subsection{Alur Kerja Prototype Perangkat Keras dan Aplikasi}

Kebutuhan prototype perangkat keras Brankas dan alur kerja dari prototype perangkat keras dan aplikasi android untuk kunci elektronik pada brankas terdapat pada gambar 3. Alur kerja dimulai dari aplikasi yang akan terhubung pada rangkaian elektronik (prototype perangkat keras brankas) melalui koneksi Bluetooth yang dijalankan melalui Android Smartphone. Komponen yang terdapat pada rangkaian prototype perangkat keras brankas adalah Selenoid Door Lock, Mikrokontroler Arduino Pro Mini, Bluetooth HC-05 Module dan Power Supply Switching 9V 1,2Ampere. Dapat dijelaskan bahwa pertama catu daya mengirim arus listrik 9V ke Arduino, Bluetooth Module, Solenoid Door Lock untuk mengaktifkannya. Setelah arus dikirim untuk mengaktifkan Bluetooth Module, Bluetooth akan menerima sinyal digital berupa string dari aplikasi smartphone ke Arduino. Sinyal akan dikirimkan dari aplikasi melalui bluetooth ke Arduino kemudian akan diproses di mikrokontroler arduino yang akan diteruskan ke Solenoid.

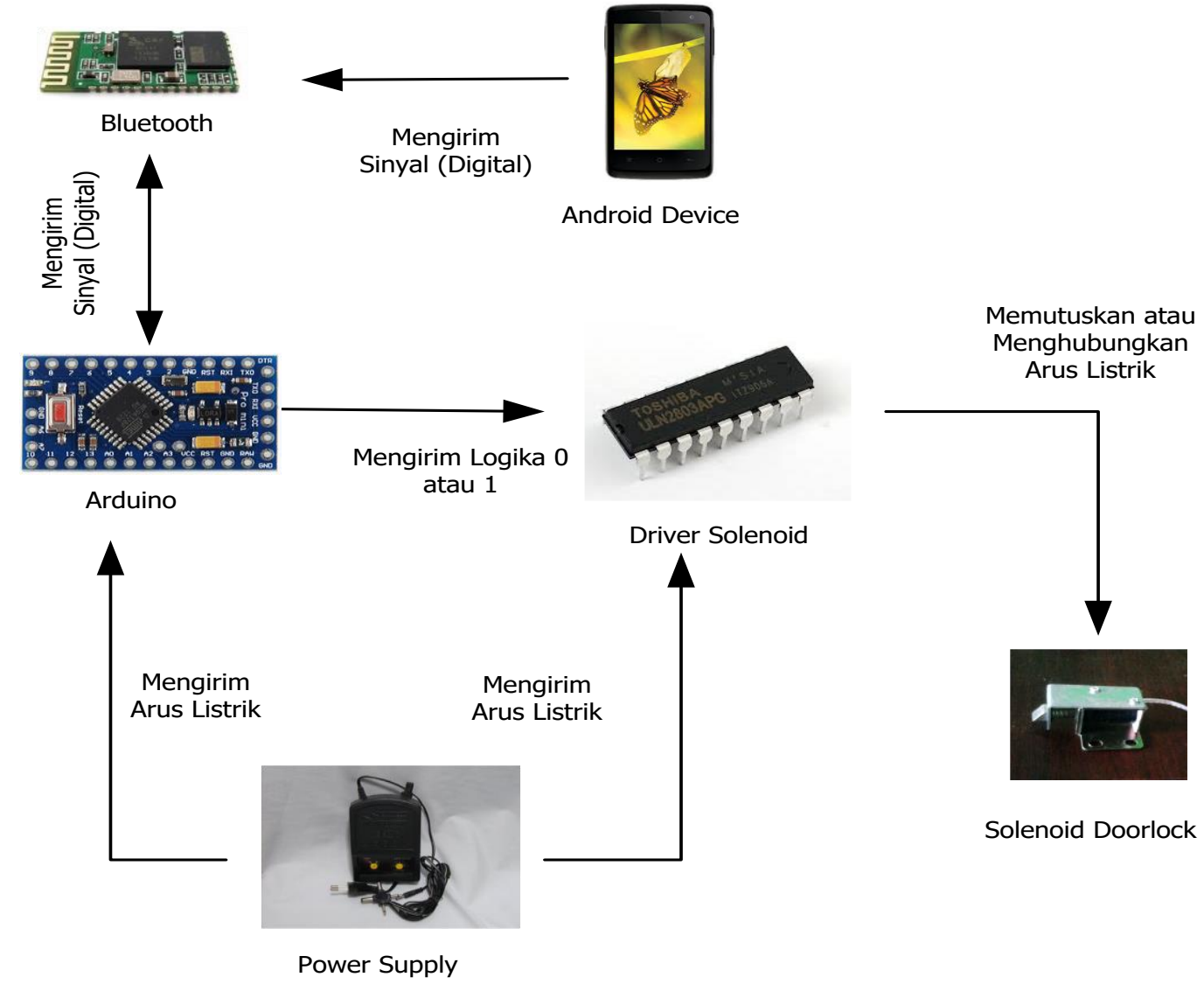

Gambar 3. Alur Kerja Prototype Perangkat Keras dan Aplikasi Android untuk Kunci Elektronik Pada Brankas

Aplikasi dapat dijalankan jika smartphone sudah terhubung dengan Arduino melalui bluetooth. User harus login terlebih dulu dengan mengisi textfield username dan password. Setelah berhasil login maka User diarahkan ke menu utama yang terdapat beberapa pilihan menu, menu tersebut adalah Kontrol, User, LOG dan Bantuan. Jika User ingin membuka atau mengunci brankas maka User harus memilih atau menekan Menu Kontrol. Menu User berfungsi untuk User yang ingin mengubah data berupa username dan password. Lalu menu LOG berfungsi untuk melihat histori atau riwayat User yang login maupun logout. Sedangkan, jika User ingin mengetahui penjelasan tentang menu-menu utama dapat memilih Menu Bantuan.

\subsection{Rancangan Perangkat Keras}

Rangkaian interface pada aplikasi android untuk kunci elektronik pada brankas berfungsi sebagai pengendali yang cara kerjanya adalah membaca sinyal digital melalui Bluetooth pada mikrokontroler yang dikirimkan oleh Android berupa string untuk membuka atau mengunci pintu brankas. Rangkaian interface tersebut terdiri dari komponen elektronik diantaranya mikrokontroler Arduino Promini, Bluetooth Module, Driver Solenoid, Solenoid Doorlock dan adaptor (Power Supply). Dari komponen-komponen tersebut saling dihubungkan seperti adaptor dengan Arduino Promini lalu dihubungkan dengan Bluetooth, Driver Solenoid dan Solenoid Doorlock. Rancangan perangkat keras seperti terlihat pada gambar Error! Reference source not found.4. 


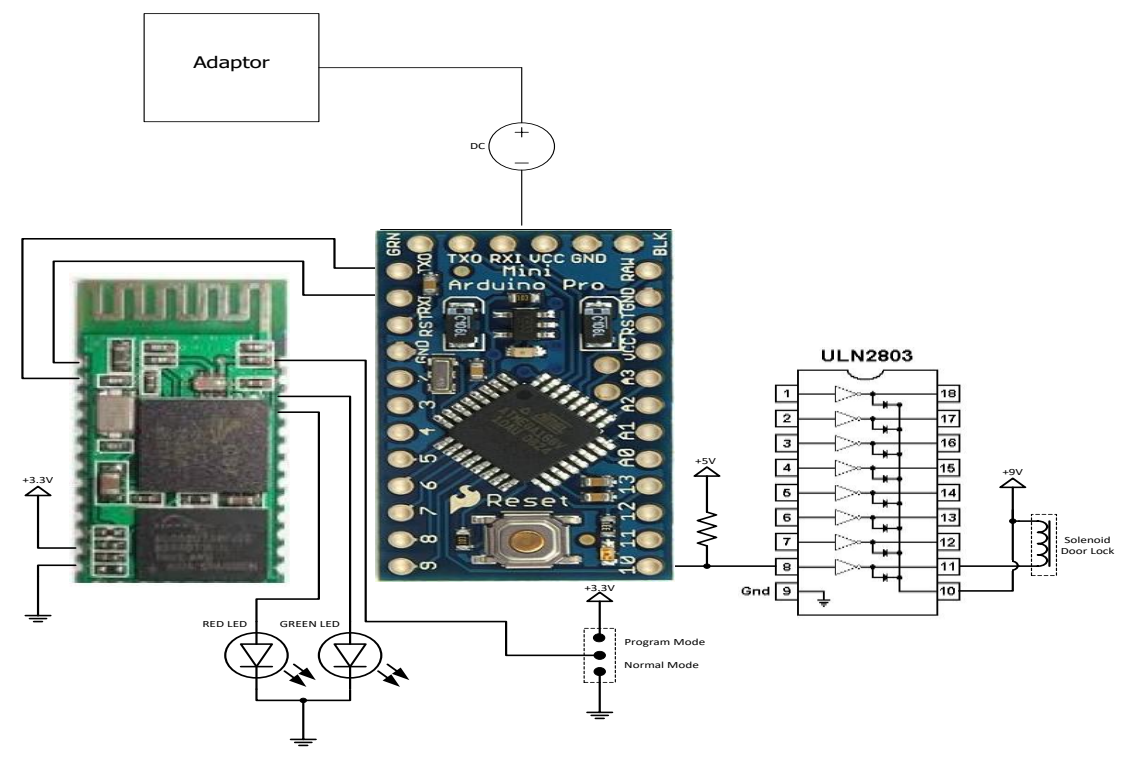

Gambar 4. Rangkaian Perangkat Keras

\subsection{Rancangan Basis Data}

Basis data digunakan untuk menyimpan data pengguna dan riwayat pengguna brankas. Aplikasi menggunakan dua buah tabel untuk menyimpan data, yaitu tabel admin dan tabel history. Tabel Admin digunakan untuk menyimpan pengguna yang berhak membuka dan menutup brankas. Spesifikasi tabel Admin dapat dilihat pada Tabel 1.

Tabel 1. Tabel Admin

\begin{tabular}{cccc}
\hline Nama Field & Tipe & Lebar & Deskripsi \\
\hline Id_log & integer & 1 & No Id user \\
user & text & 10 & Nama user \\
Status & text & 6 & Login atau Logout \\
Jam & text & 9 & Jam \\
Tanggal & text & 12 & Tanggal \\
\hline
\end{tabular}

Tabel History digunakan untuk menyimpan riwayat pengguna dalam menggunakan aplikasi. Spesifikasi tabel Admin dapat dilihat pada Tabel 2.

Tabel 2. Tabel History

\begin{tabular}{cccc}
\hline Nama Field & Tipe & Lebar & Deskripsi \\
\hline Id_log & integer & 1 & No Id user \\
User & text & 10 & Nama user \\
Status & text & 6 & Login atau Logout \\
Jam & text & 9 & Jam \\
Tanggal & text & 12 & Tanggal \\
\hline
\end{tabular}

\subsection{Pengkodean dan Perakitan}

Pada tahap berikutnya adalah pembuatan kode program dan perakitan perangkat keras sesuai dengan proses modeling yang sudah dirancang sebelumnya.

1. Mengunggah Program Arduino

Langkah awal yang dilakukan adalah menghubungkan mikrokontroler dengan komputer dengan memasang kabel USB2serial pada port mikrontroler seperti terlihat gambar 5.

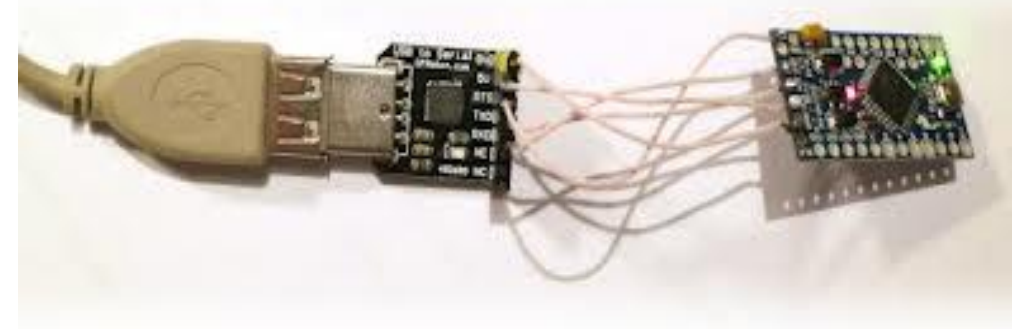

Gambar 5. Menghubungkan Mikrontroler dengan USB2serial 
JURNAL MEDIA INFORMATIKA BUDIDARMA

Volume 4, Nomor 3, Juli 2020, Page 693-699

ISSN 2614-5278 (media cetak), ISSN 2548-8368 (media online)

Available Online at https://ejurnal.stmik-budidarma.ac.id/index.php/mib

DOI 10.30865/mib.v4i3.2189

Berikutnya membuat baris program dengan menggunakan IDE BAscom AVR. Pembuatan baris program agar mikrokontroler dapat membaca input sinyal digital dari Bluetooth dan diteruskan ke solenoid. Setelah baris program selesai dibuat kemudian file dapat disimpan dan di-compile.

2. Instalasi Rangkaian Alat

Berikutnya instalasi rangkaian alat dengan sambungan berikut ini:

a. kaki komponen Bluetooth yaitu Pin 1 (TX), Pin 2 (RX), Pin 12 (VCC), dan Pin 13 (GND) pada board dihubungkan pada mikrokontroler Arduino.

b. Pin 1 (TX) bluetooth pada Port (RX) atau Port D0 Arduino.

c. Pin 2 (RX) bluetooth pada Port (TX) atau port D1 Arduino.

d. Pin 12 (VCC) bluetooth pada Port VCC 3,3 Volt Arduino.

e. Pin 13 (GND) bluetooth pada Port GND 2 Arduino.

f. Kaki komponen ULN 2803 yaitu Pin In 8, Pin Out 10 dan Pin Out 11 pada Arduino dan Solenoid.

g. Pin In 8 ULN 2803 pada Port B2 Arduino.

h. Pin Out 10 ULN 2803 pada port 5 volt Arduino.

i. Pin Out 11 ULN pada Solenoid Dorlock.

Hasil rakit rangkaian alat terlihat pada gambar 6.

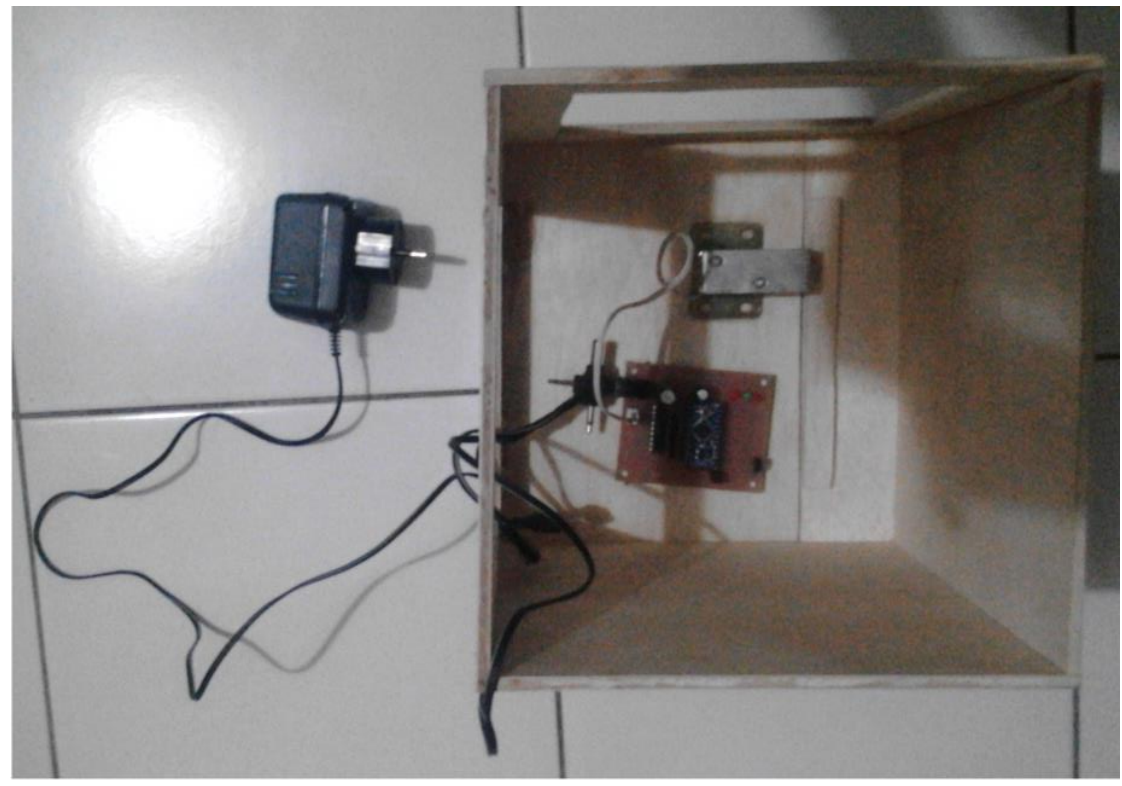

Gambar 6. Rangkaian Alat Pada Kotak Simulasi Brankas

3. Membuat Aplikasi Android

Berikutnya membuat aplikasi berbasis Android. Fitur yang dibangun diantaranya:

a. Form Login

Ketika pertama kali aplikasi dibuka, maka ditampilkan form login dengan dua field yang harus diisi yaitu username dan password. Ketika tombol login ditekan, akan diperiksa apakah username dan password sesuai dengan yang ada di database. Jika benar, maka akan menampilkan Menu Uama, sedangkan jika salah akan menampilkan informasi gagal login.

b. Menu Utama

Terdapat beberapa pilihan menu yang bisa digunakan yaitu Menu Kontrol, Menu User, Menu Log, Menu Bantuan dan Tombol Logout. Ketika tombol logout ditekan maka sesi akan berakhir dan aplikasi akan keluar.

c. Menu Kontrol

Terdapat dua tombol, yaitu tombol "Lock" untuk mengunci brankas, dan "Unlock" untuk membuka kunci brankas.

d. Menu User

Digunakan untuk mengubah data user.

e. Menu Log

Digunakan untuk melihat riwayat pengguna masuk dan keluar dari aplikasi.

f. Menu Bantuan

Menampilkan informasi fitur / menu yang ada pada aplikasi

Hasil dari pembuatan aplikasi dapat dilihat pada 7 . 
ISSN 2614-5278 (media cetak), ISSN 2548-8368 (media online)

Available Online at https://ejurnal.stmik-budidarma.ac.id/index.php/mib

DOI 10.30865/mib.v4i3.2189
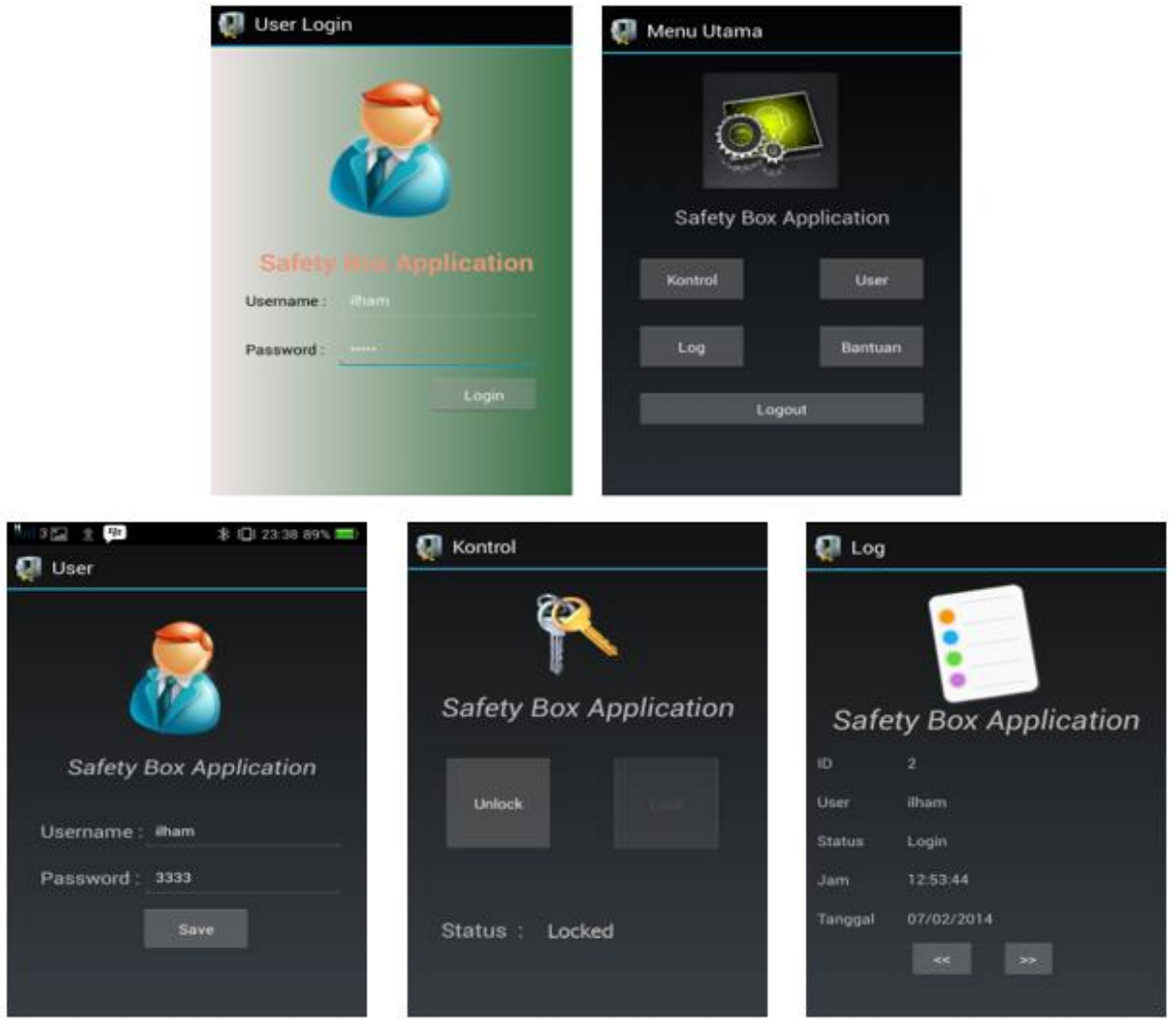

Gambar 7. Aplikasi Android Kunci Elektronik

\subsection{Pengujian}

Pengujian dilakukan terhadap aplikasi yang sudah dibangun untuk melihat keberhasilannya. Pengujian dilakukan menggunakan metode blackbox testing[15]. Hasil pengujian dapat dilihat pada Tabel 3.

Tabel 3. Tabel Pengujian

\begin{tabular}{cllr}
\hline Form diuji & \multicolumn{1}{c}{ Pengujian } & \multicolumn{1}{c}{ Target } & Hasil \\
\hline \multirow{3}{*}{ Form Login } & Tombol Login & Jika username dan password diinput salah, keluar keterangan gagal login & sukses \\
\cline { 3 - 4 } & & Jika username dan password diinput benar, akan membuka menu utama & sukses \\
\cline { 2 - 4 } & Menu Kontrol & Membuka menu control & sukses \\
\cline { 2 - 4 } Menu Utama & Menu User & Membuka form user untuk mengubah username dan password & sukses \\
\cline { 2 - 4 } & Menu Log & Menampilkan halaman riwayat user login dan logout & sukses \\
\cline { 2 - 4 } & Menu Bantuan & Menampilkan informasi menu yang ada pada aplikasi \\
\cline { 2 - 4 } & Tombol Logout & Mengakhiri sesi, keluar aplikasi serta simpan username dan waktu logout & sukses \\
\hline \multirow{3}{*}{ Menu Kontrol } & Tombol Unlock & $\begin{array}{l}\text { Mengirim perintah buka kunci ke arduino melalui bluetooth, lalu } \\
\text { menampilkan keterangan "unlocked" pada aplikasi }\end{array}$ & sukses \\
\cline { 2 - 4 } & Tombol Lock & $\begin{array}{l}\text { Mengirim perintah kunci brankas ke arduino melalui bluetooth, lalu } \\
\text { menampilkan keterangan "locked" pada aplikasi }\end{array}$ & sukses \\
\hline Menu User & Tombol Save & $\begin{array}{l}\text { Menyimpan perubahan username dan password yang diinput oleh } \\
\text { pengguna }\end{array}$ & sukses \\
\hline
\end{tabular}

\subsection{Evaluasi Program}

Hasil evaluasi program merupakan salah satu hal yang perlu dilakukan dalam setiap pengembangan suatu aplikasi yang dibuat. Demikan juga dengan aplikasi keamanan brankas ini, juga dilakukan tahap evaluasi program dan hasil evaluasi untuk mengetahui hasil yang telah dicapai. Dalam hal ini ditemukan kelebihan dan kekurangan aplikasi ini adalah sebagai berikut:

1. Kelebihan Program 
a. Lebih efisien karena menggunakan koneksi Bluetooth jika dibandingkan dengan sistem aplikasi SMS Gateway yang membutuhkan biaya lebih yaitu pulsa untuk mengoperasikannya.

b. Aplikasi ini memiliki fitur LOG, dimana fitur yang memberikan informasi mengenai aktivitas login dan logout oleh pengguna.

c. Aplikasi kemananan brankas tidak dapat digunakan selain user, karena hanya Android Device yang sudah terpasang dengan Bluetooth yang terdapat pada rangkaian alat.

2. Kekurangan Program

a. Belum ada pemberitahuan atau alarm apabila ada yang memaksa membuka pintu brankas.

b. Program tidak dapat beroperasi jika listrik mati atau tidak adanya Power Supply.

\section{KESIMPULAN}

Setelah semua pembahasan dan penjelasan materi maupun implementasi program dikemukakan, maka penulis menarik kesimpulan mengenai pokok pembahasan bab-bab sebelumnya sebagai berikut:

1. Pengintegrasian rangkaian mikrokontroler seperti solenoid door lock, ATmega 328, Bluetooth HC-05 dan android menjadi sistem aplikasi keamanan pada brankas yang telah dibuat sesuai program menggunakan Basic4android.

2. Alat dapat melakukan respon yang baik terhadap User saat melakukan perintah dari Android melalui Bluetooth dalam jarak kurang dari 5 meter.

3. Sistem keamanan memiliki keamanan yang tinggi karena memiliki otentifikasi dan fitur LOG untuk mengetahui kegiatan terakhir (login dan logout) dari pengguna.

\section{UCAPAN TERIMAKASIH}

Terima kasih atas dukungan dan sumber pendanaan internal yang diberikan oleh Universitas Budi Luhur pada kegiatan penelitian ini sehingga penelitian berjalan dengan lancar.

\section{REFERENCES}

[1] Subdirektorat Statistik Politik dan Keamanan, "Statistik Kriminal 2019 Badan Pusat Statistik," 2089-5291, 2019.

[2] S. Sadi and M. Y. M. Pratama, "Sistem Keamanan Buka Tutup Kunci Brankas Menggunakan Bluetooth HC - 05 Berbasis Arduino Mega 2560,” J. Tek., vol. 6, no. 2, pp. 99-105, 2017.

[3] M. Wijaya and T. Susila, "Sistem keamanan brankas secara otomatis berbasis mikrokontroler dengan menggunakan sms serta pin dan rfid," TESLA, vol. 18, no. 2, pp. 139-151, 2016.

[4] Annisya, L. Hermanto, and R. Candra, "Sistem Keamanan Buka Tutup Kunci Brankas Menggunakan Sidik Jari Berbasi Arduino Mega," J. Inform. dan Komput., vol. 22, no. 1, 2017, doi: 10.1021/acs.est.7b01094.

[5] D. Nurdin Bagenda and I. Mulyana, "Perancangan Sistem Keamanan Brankas Menggunakan Kartu RFID Berbasis Arduino Pro Mini," J. LPKIA, vol. 7, no. 2, 2016.

[6] E. Yuliza and T. U. Kalsum, "Alat Keamanan Pintu Brankas Berbasis Sensor Sidik Jari Dan Passoword Digital Dengan Menggunakan Mikrokontroler Atmega 16,” J. Media Infotama, vol. 11, no. 1, 2018.

[7] H. D. Ariessanti, Radiyanto, and A. S. Yuswanto, "Pengaman Brankas Menggunakan Voice Dengan Media Bluetooth Berbasis Mikrokontrller Atmega 328," CCIT J., vol. 9, no. 1, pp. 27-32, 2015.

[8] D. Antonio, "Rancang Bangun Aplikasi Keamanan Brankas Berbasis Sinar Laser Dengan Mikrokontroller Arduino Nano Dan Uno R3," J. Sisfokom (Sistem Inf. dan Komputer), vol. 2, no. 2, 2013, doi: 10.32736/sisfokom.v2i2.90.

[9] E. Saputro, "Rancang Bangun Pengaman Pintu Otomatis Menggunakan E-KTP Berbasis Mikrokontroler Atmega328," Universitas Negeri Semarang, 2016.

[10] R. M. Syafii, M. Ikhwanus, and M. Jannah, "Desain dan Implementasi Sistem Keamanan Locker Menggunakan E-KTP Berbasis Arduino Pro Mini,” J. Energi Elektr., vol. 7, no. 2, 2018, doi: 10.29103/jee.v7i2.1058.

[11] A. Tanjung, "Sistem Keamanan Sepeda Motor dengan Fingerprint Menggunakan Arduino Pro Mini," J. Tek. Elektro, Univ. Bung Hatta, vol. 7, no. 1, pp. 1-8, 2015.

[12] B. Siregar, C. S. Nasution, D. Gunawan, S. Sawaluddin, U. Andayani, and F. Fahmi, "Security Device for Motorcycle Using Smartphone Android with Promini," in Journal of Physics: Conference Series, 2018, doi: 10.1088/17426596/1028/1/012049.

[13] A. Bazergan and A. Muis, "Rancang Bangun Sistem Pengaman Brankas Berbasis Wireless," in Prosiding Seminar Hasil Penelitian (SNP2M) 2017, 2017, pp. 189-195.

[14] L. C. PAMUNGKAS, "Sistem Pengamanan Brankas Menggunakan Bluetooth Berbasis Android," Universitas Islam Sultan Agung Semarang, 2019.

[15] T. S. Jaya, "Pengujian Aplikasi dengan Metode Blackbox Testing Boundary Value Analysis," J. Inform. J. Pengemb. IT Poltek Tegal, vol. 3, no. 1, 2018, doi: 10.30591/jpit.v3i1.647. 